\title{
EFFECTS OF SODIUM CHLORIDE ON GROWTH AND MINERAL NUTRITION OF PURPLETOP VERVAIN
}

\author{
Piotr Salachna', Rafał Piechocki ${ }^{1}$ \\ 1 Department of Horticulture, West Pomeranian University of Technology in Szczecin, Papieża Pawła VI 3 Str., \\ 71-459 Szczecin, Poland, e-mail: Piotr.Salachna@zut.edu.pl
}

Received: 2016.02.16

Accepted: 2016.03.04

Published: 2016.04 .01

\begin{abstract}
There is a rising demand for salt-tolerant species for landscaping. Purpletop vervain is an excellent landscape plant for gardens and parks, with fragrant lavender to rosepurple flowers. However, little is known concerning the effect of sodium chloride on morphological characteristics, flowering and mineral uptake of purpletop vervain. In this study, carried out in 2013-2014, the plants of purpletop vervain were grown in pots in an unheated plastic tunnel. The plants were watered with $200 \mathrm{mM} \mathrm{NaCl}$ solution four times, every seven days. Salinity-exposed plants were characterized by slightly reduced plant height, weight of the aboveground part and visual score. Salt stress caused also an increase in leaf content sodium, chlorine and manganese. Salinity had no effect on earliness of flowering and content in leaves of phosphorus, potassium, magnesium, copper, zinc and iron. Purpletop vervain seems to be plant species able to tolerate salt stress under controlled conditions.
\end{abstract}

Keywords: ion concentration, salinity stress, Verbena bonariensis, clustertop vervain.

\section{INTRODUCTION}

Salinity is one of the most serious environmental problems in cultivation of ornamental plants in urban areas [Wrochna et al., 2010; Cassaniti et al., 2012]. It is well-known that salinity causes stunting, chlorosis and necrosis, leading to a reduction in plant quality [Marschner, 1995]. Salt stress affects all major processes and plant metabolism such as growth, flowering, photosynthesis, respiration, water potential, enzymatic activity, absorption of minerals and nutrient balance [Cassaniti et al., 2013; Parihar et al., 2015]. However, for ornamental plants, visual quality is more important than growth rate [Niu and Cabrera, 2010]. There is a rising demand for landscape plants whose aesthetic values are not or are only slightly affected by salt stress [Niu et al., 2013].

Verbena (Verbena L.) is a genus in the Verbenaceae containing 211 species indigenous to Americas and Europe [Erhardt et al., 2014]. Of all the verbenas, purpletop vervain $(V$. bonariensis L.) is among the tallest species and particu- larly effective as a ornamental plant [Armitage and Laushman, 2008]. This species is annual or herbaceous perennial, with fragrant lavender to rose-purple flowers in tight clusters located on stems with very long internodes [Grossman et al., 2014]. Purpletop vervain is an excellent landscape plant for gardens and parks. However, little is known about the response of purpletop vervain to salt stress.

The objective of this study was to investigate the effect of sodium chloride on the growth, flowering, ecophysiological parameters, visual quality relative, and nutritional status of purpletop vervain.

\section{MATERIALS AND METHODS}

The experiment was carried out in the years 2013-2014 at the West Pomeranian University of Technology in Szczecin $\left(53^{\circ} 25^{\prime} \mathrm{N}, 14^{\circ} 32^{\prime} \mathrm{E}\right.$, $25 \mathrm{~m}$ a.s.1.). Seeds of purpletop vervain (Verbena bonariensis L.) were purchased from the W. Legutko Breeding and Seed Company Ltd., Jutrosin, 
Poland. On 10 March 2013 and 12 March 2014 seeds were sown into boxes filled with substrates. Seeds were germinated under dark conditions in an environmentally controlled glasshouse (21/17 ${ }^{\circ} \mathrm{C}$ day/night; $\mathrm{RH}$ 80-90\%). After germination, the seedlings were planted in the pots with a capacity of $0.4 \mathrm{dm}^{3}$ containing a deacidified peat (pH 6.5), supplemented with $1 \mathrm{~g} \cdot \mathrm{dm}^{-3}$ of a fertilizer Azofoska (Grupa INCO S.A., Poland; containing $8.1 \% \mathrm{~N}-\mathrm{NH}_{4}, 5.5 \% \mathrm{~N}^{-\mathrm{NO}_{3}}, 6.4 \% \mathrm{P}_{2} \mathrm{O}_{5}$, $19.1 \% \mathrm{~K}_{2} \mathrm{O}, 4.5 \% \mathrm{MgO}, 23.0 \% \mathrm{SO}_{3}, 0.045 \%$ $\mathrm{B}, 0.18 \% \mathrm{Cu}, 0.17 \% \mathrm{Fe}, 0.27 \% \mathrm{Mn}, 0.04 \% \mathrm{Mo}$, $0.045 \% \mathrm{Zn}$, and $\mathrm{Cl}>0.4 \%$ ). On 15 May 2013 and 16 May 2014 one plant was maintained in each PCV pot with a capacity of $5 \mathrm{dm}^{3}$. The pots were filed with a deacidified peat substrate $(\mathrm{pH}$ 6.5) with a mixture of fertilizer Azofoska $\left(3 \mathrm{~g} \cdot \mathrm{dm}^{-3}\right)$. The plants were grown in an unheated plastic tunnel under natural photoperiod. The pots were watered three times a week using tap water. The mean ion concentration $\left(\mathrm{mg} \cdot \mathrm{dm}^{-3}\right)$ in tap water were: $1.53 \mathrm{~N}^{-\mathrm{NO}_{3}}, 1.5 \mathrm{P}, 6.2 \mathrm{~K}, 97.4 \mathrm{Ca}, 16.6$ $\mathrm{Mg}, 24.0 \mathrm{Na}, 24.0 \mathrm{Cl}, 0.62 \mathrm{Cu}, 0.42 \mathrm{Zn}, 1.3 \mathrm{Fe}$, $194 \mathrm{HCO}_{3}$, EC $0.65 \mathrm{mS} \cdot \mathrm{cm}^{-1}$. The plants exposed to salinity stress were watered with $200 \mathrm{mM}$ $\mathrm{NaCl}$ solution four times, every seven days from 1 June 2013 and 2014. Each time one plant in a pot was watered with $500 \mathrm{ml}$ of the salt solution. Control plants were treated with tap water. The beginning of plant flowering was determined by counting the number of days from sowing to the day of opening of the first flower in inflorescence. At the beginning of flowering the ecophysiological parameters were assessed. The relative chlorophyll content was measured with the N-Tester chlorophyll meter (Yara International ASA, Oslo, Norway). The measurements included ten leaves located in the middle of a plant and three readings were taken per each leaf. Stomatal conductance was assessed with $\mathrm{SC} 1$ porometer (Dekagon Devices, USA). The measurements were performed only on sunny days between 10 a.m. and 12 p.m., and included six leaves per plant. The plants were cultivated under natural photoperiod until 20 August 2013 and 17 August 2014. Total plant height, number of inflorescences, fresh weight of aboveground part and visual plant quality (on a rating scale $1-5$, where 5 was the best ornamental value, and 1 was poor ornamental value) were estimated on the last day of the cultivation. The collected leaves were dried, ground and sent to an accredited laboratory of the Chemical and Agricultural Station in Szczecin for determination of nutrient content according to standard methods [Ostrowska et al., 1991].

Each treatment was replicated four times and each replicated included 10 plants. The pots were arranged in a completely randomized design. The mean values were calculated using the analysis of variance ANOVA using the Statistica 10.0 software (Statsoft, Poland), and the significance of differences between means was tested using Duncan's multiple range test at a $P \leq 0.05$.

\section{RESULTS AND DISCUSSION}

Statistical analysis of the results showed that $\mathrm{NaCl}$ treatment reduced plant height, compared with the control by $6 \%$ in the first and $16 \%$ in the second year of the study (Table 1). Measurements of plants indicated that the fresh weight of aboveground part was decreased under saline irrigation in both seasons. In comparison with the control, $\mathrm{NaCl}$ treatment was reduced fresh weight of plants by $10 \mathrm{~g}$ in 2013 and $9 \mathrm{~g}$ in 2014. Growth inhibition of salt-treated plants was also reported for other species use in urban landscaping such as Salvia splendens 'Flare Path', Coleus blumei 'Xenia Field' [Ibrahim et al. 1991], Tagetes patula 'French Vanilla', Tagetes erecta 'Flagstaff', T. erecta 'Yellow Climax' [Valdez-Aguilar et al. 2009], Lobelia erinus [Escalona et al. 2013], and Plectranthus forsteri 'Nico' [Krzymińska and Ulczycka-Walorska 2015]. For ornamental plants, being compact and free foliar damage is more significant than maximum growth [Niu et al. 2013]. Therefore, sodium chloride may have a potential benefit of acting as a growth retardant [Lee and Iersel 2008].

Salinity effect on the number of inflorescences per plant varied with years of experiment (Table 1). In 2013 salinity treatment had no effect on the number of inflorescences per plant. In $2014 \mathrm{NaCl}$ treatment significantly reduced the number of inflorescences. According to the results presented in a few studies, the number of inflorescences in ornamental plants may increases under salt stress [Shillo et al. 2002], decreases [Veatch-Blohm et al. 2012] or remains unchanged [Salachna et al. 2016].

In 2014, the negative effects of salt on the ecophysiological parameters were observed. The stomatal conductance ranged from $96.8 \mathrm{mmol}$ $\mathrm{H}_{2} \mathrm{O} \mathrm{m}^{-2} \mathrm{~s}^{-1}$ in the control to $77.9 \mathrm{mmol} \mathrm{H}_{2} \mathrm{O} \mathrm{m}^{-2}$ $\mathrm{s}^{-1}$ in the $\mathrm{NaCl}$ treatment and the value of $\mathrm{N}$-tes- 
Table 1. Effect of sodium chloride on plant height, fresh weight of aboveground part, earliness of flowering, number of inflorescences, stomatal conductance, N-tester values, and visual score of purpletop vervain (Verbena bonariensis L.)

\begin{tabular}{|c|c|c|c|c|}
\hline \multirow{3}{*}{ Trait } & \multicolumn{4}{|c|}{ Treatment } \\
\hline & \multicolumn{2}{|c|}{2013} & \multicolumn{2}{|c|}{2014} \\
\hline & Control & $\mathrm{NaCl}$ & Control & $\mathrm{NaCl}$ \\
\hline \multirow{2}{*}{ Total plant height $(\mathrm{cm})$} & $161 \mathrm{a}$ & $151 \mathrm{~b}$ & $164 \mathrm{a}$ & $138 \mathrm{~b}$ \\
\hline & \pm 1.41 & \pm 0.71 & \pm 0.71 & \pm 1.41 \\
\hline \multirow{2}{*}{$\begin{array}{l}\text { Fresh weight of aboveground } \\
\text { part }(\mathrm{g})\end{array}$} & $283 a$ & $273 b$ & $231 \mathrm{a}$ & $222 \mathrm{~b}$ \\
\hline & \pm 0.78 & \pm 0.71 & \pm 6.22 & \pm 0.57 \\
\hline \multirow{2}{*}{ Earliness of flowering (days) } & $114 a$ & $116 \mathrm{a}$ & $124 \mathrm{a}$ & $124 \mathrm{a}$ \\
\hline & \pm 3.51 & \pm 4.04 & \pm 4.09 & \pm 5.26 \\
\hline \multirow{2}{*}{$\begin{array}{l}\text { Number of inflorescences per } \\
\text { plant }\end{array}$} & $9.00 \mathrm{a}$ & $8.50 \mathrm{a}$ & $8.00 \mathrm{a}$ & $7.25 \mathrm{~b}$ \\
\hline & \pm 0.00 & \pm 0.71 & \pm 0.00 & \pm 0.35 \\
\hline \multirow{2}{*}{$\begin{array}{l}\text { Stomatal conductance } \\
\left(\mathrm{mmol} \mathrm{H}_{2} \mathrm{O} \mathrm{m}^{-2} \mathrm{~s}^{-1}\right)\end{array}$} & $121 \mathrm{a}$ & $113 a$ & 96.8 a & $77.9 \mathrm{~b}$ \\
\hline & \pm 8.01 & \pm 5.87 & \pm 5.44 & \pm 6.29 \\
\hline \multirow{2}{*}{$\mathrm{N}$-tester values } & 409 a & 404 a & 394 a & $374 \mathrm{~b}$ \\
\hline & \pm 4.24 & \pm 6.36 & \pm 6.36 & \pm 2.83 \\
\hline \multirow{2}{*}{ Visual score } & $5.00 \mathrm{a}$ & $4.70 \mathrm{~b}$ & $5.00 \mathrm{a}$ & $4.13 \mathrm{~b}$ \\
\hline & \pm 0.00 & \pm 0.27 & \pm 0.00 & \pm 0.25 \\
\hline
\end{tabular}

Values are means $(\mathrm{n}=24-40) \pm$ standard deviation. Mean values in each row for each year followed by different lower-case letters were significantly different at $P \leq 0.05$ by Duncan's Multiple Range test.

ter ranged from 394 in the control to 374 in the $\mathrm{NaCl}$ treatment. However, salinity had no effect on specified parameters in the first year of experiment (Table 1). These results may indicate that in each year there were different environmental conditions of experiment. In addition to being species specific, salt tolerance of ornamental plants used in urban landscaping is the combined result of the complex interaction among climatic condition, type of soil and irrigation method [Wu et al., 1995; Niu et al., 2007; Cassaniti et al., 2012; Cassaniti et al., 2013].

The days to flowering ranged between 114 and 124 , and the time was not affected by salinity (Table 1). Similarly, no significant effect of salt treatment was found on flowering time of Zantedeschia aetiopica cultivars [Veatch-Blohm and Morningstar, 2001]. All plants in the control had a visual scores of 5.0 in both years of the study (Table 1). The visual quality of plants under salt stress was slightly decreased, with a rating of 4.70 points in 2013 and 4.13 points in 2014, which were considered acceptable for landscape.

Concentration of phosphorus, potassium, magnesium, copper, zinc and iron in leaves remained unaffected by the addition of $\mathrm{NaCl}$ (Table 2). Sodium as well as chloride content were increased in leaves of plants on exposure to salinity stress in both years of experiment. Analysis of the mineral composition of the plants grown under saline conditions help to understand the mechanism of salinity tolerance [Niu et al., 2013]. Numerous studies have demonstrated that the excessive accumulation of ions, especially sodium and chloride may limit the uptake of other ions [Wrochna et al., 2006; Lee and van Iersel, 2008; Acosta-Motos et al., 2014]. In the second year of the present study, $\mathrm{NaCl}$ treatment significantly reduced the content of nitrogen and calcium in leaves in comparison with the control, respectively by $17 \%$ and $15 \%$ (Table 2). Elevated salinity has shown a decrease in leaf nitrogen concentration in Gazania splendens [García-Caparrós et al., 2016] and Grewia tenax [Saied et al., 2010]. In a recent study, decreased in tissue $\mathrm{Ca}^{+}$concentration were observed with increased salinity in Celosia argentea [Carter et al., 2005], Ranunculus asiaticus 'Yellow ASD', R. asiaticus 'Pink CTD' [Valdez-Aguilar et al., 2009], Salvia splendens 'Scarlet Piccolo' and Helianthus annus 'Teddy Bear' [Breś et al., 2014]. Decreased nitrogen uptake in response to external $\mathrm{NaCl}$ salinity occurs due to antagonism between $\mathrm{Na}^{+}$and $\mathrm{NH}_{4}^{+}$ and/or between $\mathrm{Cl}^{-}$and $\mathrm{NO}_{3}{ }^{-}$[Parihar et al., 2015].

$\mathrm{NaCl}$ treatment induced a significant increase in leaf manganese concentration, in comparison with the control by $6 \%$ in 2013 and $8 \%$ in 2014 (Table 2). Increased manganese leaf content under salt stress was also reported in Ziziphus mauritiana [Bhatt et al., 2008] Chrysanthemum morifolium 'Yellow Blush' [Lee and van Iersel, 2008] and Plectranthus ciliatus [Salachna et al., 2015]. 
Table 2. Effect of sodium chloride on macro and micronutrients concentration in the leaves of purpletop vervain (Verbena bonariensis L.)

\begin{tabular}{|c|c|c|c|c|}
\hline \multirow{3}{*}{ Nutrient } & \multicolumn{4}{|c|}{ Treatment } \\
\hline & \multicolumn{2}{|c|}{2013} & \multicolumn{2}{|c|}{2014} \\
\hline & Control & $\mathrm{NaCl}$ & Control & $\mathrm{NaCl}$ \\
\hline Nitrogen - total (\% DW) & $0.64 \mathrm{a} \pm 0.02$ & $0.65 a \pm 0.05$ & $0.54 a \pm 0.05$ & $0.45 b \pm 0.01$ \\
\hline Phosphorus (\% DW) & $0.19 a \pm 0.01$ & $0.20 \mathrm{a} \pm 0.01$ & $0.20 \mathrm{a} \pm 0.02$ & $0.22 \mathrm{a} \pm 0.01$ \\
\hline Potassium (\% DW) & $0.41 \mathrm{a} \pm 0.03$ & $0.38 a \pm 0.02$ & $0.40 a \pm 0.01$ & $0.40 a \pm 0.01$ \\
\hline Calcium (\% DW) & $3.10 a \pm 0.13$ & $3.20 \mathrm{a} \pm 0.13$ & $2.50 a \pm 0.14$ & $2.12 b \pm 0.12$ \\
\hline Magnesium (\% DW) & $0.29 \mathrm{a} \pm 0.01$ & $0.30 \mathrm{a} \pm 0.01$ & $0.29 a \pm 0.02$ & $0.30 a \pm 0.01$ \\
\hline Sodium (\% DW) & $0.03 b \pm 0.02$ & $0.07 a \pm 0.02$ & $0.02 b \pm 0.01$ & $0.08 a \pm 0.04$ \\
\hline Chlorine (\% DW) & $0.31 b \pm 0.03$ & $0.72 \mathrm{a} \pm 0.04$ & $0.44 b \pm 0.05$ & $0.71 \mathrm{a} \pm 0.02$ \\
\hline Copper (mg kg-1 DW) & $2.00 \mathrm{a} \pm 0.13$ & $1.94 a \pm 0.09$ & $1.99 a \pm 0.02$ & $1.93 a \pm 0.10$ \\
\hline Zinc (mg kg-1 DW) & $31.0 \mathrm{a} \pm 2.76$ & $29.6 a \pm 2.26$ & $28.9 a \pm 1.20$ & $29.1 \mathrm{a} \pm 1.34$ \\
\hline Manganese (mg kg-1 DW) & $119 b \pm 1.41$ & 126 a \pm 1.41 & $116 b \pm 5.66$ & $125 \mathrm{a} \pm 7.07$ \\
\hline Iron (mg kg-1 DW) & $111 \mathrm{a} \pm 6.36$ & $118 a \pm 3.54$ & $127 \mathrm{a} \pm 4.24$ & $120 \mathrm{a} \pm 7.07$ \\
\hline
\end{tabular}

DW - dry weight. Values are the means of three replicate ( \pm standard deviation). Mean values in each row for each year followed by different lower-case letters were significantly different at $P \leq 0.05$ by Duncan's Multiple Range test.

Manganese is an essential trace element for plants and it is an activator of a number of different enzymes in plant systems, mostly in oxidation, reduction, decarboxylation and hydrolytic reactions [Marschner, 1995]. Shahi and Srivastava [2016] demonstrated that foliar spraying with manganese has a crucial role for increasing tolerance of mungbean plants to salinity stress. Increased manganese concentration in leaves of purpletop vervain treated $\mathrm{NaCl}$ may be due to a participation of this nutrient in the process of adaptation to salt stress condition.

\section{CONCLUSION}

This study has demonstrated that salinity stress slightly reduced plant height, weight of the aboveground part and visual score in purpletop vervain. Moreover, the leaves of salt-exposed plants contained more sodium, chlorine and manganese. Salinity had no effect on earliness of flowering and content in leaves of phosphorus, potassium, magnesium, copper, zinc and iron. Purpletop vervain seems to be plant species tolerant to salinity and may be uses in urban landscape exposed to salt stress.

\section{Acknowledgements}

This study was supported by the Polish Ministry of Science and Higher Education, within the project UPB 518-07-014-3176-02/18 ZUT.

\section{REFERENCES}

1. Acosta-Motos J.R., Alvarez S., Barba-Espin G., Hernandez J.A., Sanchez-Blanco M.J. 2014. Salts and nutrients present in regenerated waters induce changes in water relations, antioxidative metabolism, ion accumulation and restricted ion uptake in Myrtus communis L. plants. Plant Physiol. Biochem., 85, 41-50.

2. Armitage A.M., Laushman J.M. 2008. Specialty cut flowers. The production of annuals, perennials, bulbs, and woody plants for fresh and dried cut flowers. Timber Press, Portland, London, 525-528.

3. Bhatt M.J., Patel A.D., Bhatti P.M., Pandey A.N. 2008. Effect of soil salinity on growth, water status and nutrient accumulation in seedlings of Ziziphus mauritiana (Rhamnaceae). Fruit. Ornam. Plant Res., 16, 383-401.

4. Breś W., Kupska A., Trelka T. 2014. Response of scarlet sage and common sunflower plants to salinity caused by sodium salts. Folia Pomer. Univ. Technol. Stetin., Agric., Aliment., Pisc., Zootech., 315 (32), 5-14.

5. Carter C.T., Grieve C.M., Poss J.A., Suarez D.L. 2005. Production and ion uptake of Celosia argentea irrigated with saline wastewaters. Sci. Hortic., 106 (3), 381-394.

6. Cassaniti C., Romano D., Flowers T.J. 2012. The response of ornamental plants to saline irrigation water, irrigation - water management, pollution and alternative strategies. Edited by Iker GarciaGarizabal. InTech, 131-158.

7. Cassaniti C., Romano D., Hop M.E.C.M., Flowers 
T.J. 2013. Growing floricultural crops with brackish water. Environ. Exp. Bot., 92, 165-175.

8. Erhardt W., Götz E., Bödeker N., Seybold S. 2014. Zander. Handwörterbuch der Pflanzennamen. Ulmer. Stuttgart, 787.

9. Escalona A., Salas M.C., Coutinho C.D.S., Guzman M. 2013. How does salinity affect mineral ion relations and growth of Lobelia erinus for use in urban landscaping? J. Food Agric. Environ., 11 (2), 854-858.

10. García-Caparrós P., Llanderal A., Pestana M., Correia P.J., Lao M.T. 2016. Tolerance mechanisms of three potted ornamental plants grown under moderate salinity. Sci. Hortic., 201, 84-91.

11. Grossman M., Freeborn J., Scoggins H., Latimer J. 2014. Effects of application time of benzyladenine on the branching and growth of herbaceous perennial liners. Acta Hortic., 1042, 237-242.

12. Ibrahim K.M., Collins J.C. Collin H.A. 1991. Effects of salinity on growth and ionic composition of Coleus blumei and Salvia splendens. J. Hortic. Sci., 66 (2), 215-222.

13. Krzymińska A., Ulczycka-Walorska M. 2015. The effect of sodium chloride on growth and quality of Plectranthus forsteri Benth. 'Nico'. J. Hort. Res., 23 (1), 17-20.

14. Lee M.K., van Iersel M.W. 2008. Sodium chloride effects on growth, morphology, and physiology of chrysanthemum (Chrysanthemum ×morifolium). HortScience, 43 (6), 1888-1891.

15. Marschner, H. 1995. Mineral nutrition of higher plants (2nd ed.). Academic Press, New York.

16. Niu G., Cabrera R.I. 2010. Growth and physiological responses of landscape plants to saline water irrigation: A review. HortScience, 45 (11), 1605-1609.

17. Niu G., Rodriguez D.S., Aguiniga L. 2007. Growth and landscape performance of ten herbaceous species in response to saline water irrigation. J. Environ. Hortic., 25 (4), 204-210.

18. Niu G., Starman T., Byrne D. 2013. Responses of growth and mineral nutrition of garden roses to saline water irrigation. HortScience, 48 (6), 756-761.

19. Ostrowska A., Gawliński S., Szczubiałka Z. 1991. Metody analizy i oceny właściwości gleb i roślin. Instytut Ochrony Środowiska. Warszawa.

20. Parihar P., Singh S., Singh R., Singh V.P., Prasad S.M. 2015. Effect of salinity stress on plants and its tolerance strategies: a review. Environ. Sci. Pollut. R., 22 (6), 4056-4075.

21. Saied A.S., Sohail M., Gebauer J., Buerkert A. 2010. Response of Grewia tenax (Forssk.) Fiori to NaClinduced salinity Eur. J. Hortic. Sci., 75 (1), 42-50.

22. Salachna P., Piechocki R., Zawadzinska A., Woskowiak A. 2015. Response of speckled spur-flower to salinity stress and salicylic acid treatment. J. Ecol. Eng., 16 (5), 68-75.

23. Salachna P., Zawadzińska A., Podsiadło C. 2016. Response of Ornithogalum saundersiae Bak. to salinity stress. Acta Sci. Pol., Hortorum Cultus, 15(1), 123-134..

24. Shahi S., Srivastava M. 2016. Foliar application of manganese for increasing salinity tolerance in mungbean. Int. J. Appl. Biol. Pharm., 7 (1), 148-153.

25. Shillo, R., Ding, M., Pasternak, D., Zaccai, M. 2002. Cultivation of cut flower and bulb species with saline water. Sci. Hortic., 92 (1), 41-54.

26. Valdez-Aguilar L.A., Grieve C.M., Poss J. 2009. Salinity and alkaline $\mathrm{pH}$ in irrigation water affect marigold plants: I. Growth and shoot dry weight partitioning. HortScience, 44 (6), 1719-1725.

27. Valdez-Aguilar L.A., Grieve C.M., Poss J., Mellano M.A. 2009. Hypersensitivity of Ranunculus asiaticus to salinity and alkaline $\mathrm{pH}$ in irrigation water in sand cultures HortScience, 44 (1), 138-144.

28. Veatch-Blohm M.E., Malinowski M., Keefer D. 2012. Leaf water status, osmotic adjustment and carbon assimilation in colored calla lilies in response to saline irrigation. Sci. Hortic., 144, 65-73.

29. Veatch-Blohm, M.E., Morningstar, L. 2011. Calla lily growth and development under saline irrigation. HortScience, 46 (2), 222-227.

30. Wrochna M., Gawrońska H., Gawroński S.W., 2006. Wytwarzanie biomasy i akumulacja jonów $\mathrm{Na}^{+}, \mathrm{K}^{+}, \mathrm{Ca}^{2+}, \mathrm{Mg}^{2+}, \mathrm{Cl}^{-} \mathrm{w}$ warunkach stresu solnego, przez wybrane gatunki roślin ozdobnych. Acta Agrophysica, 134, 775-785.

31. Wrochna M., Małecka-Przybysz M., Gawrońska H. 2010. Effect of road deicing salts with anti corrosion agents on selected plant species. Acta Sci. Pol., Hortorum Cultus, 9 (4), 171-182.

32. Wu L.J., Chen H., Lin P., Van Mantgem Harivandi M.A., Harding J.A. 1995. Effects of regenerant wastewater irrigation on growth and ion uptake of landscape plants. J. Environ. Hort., 13(4), 92-96. 